\title{
El «milagro» fotográfico. Trampantojos y resurrecciones en la era digital
}

Pilar Carrera

Profesora Titular (Universidad Carlos III de Madrid)

\section{Referencia de este artículo}

Carrera, Pilar (2021). El «milagro» fotográfico. Trampantojos y resurrecciones en la era digital. En: adComunica. Revista Científica de Estrategias, Tendencias e Innovación en Comunicación, $\mathrm{n}^{0} 22$. Castellón de la Plana: Departamento de Ciencias de la Comunicación de la Universitat Jaume I, 373-376. DOI: http://dx.doi. org/10.6035/2174-0992.2021.22.20

En el libro El color del tiempo, una historia visual del mundo 1850-1960 (2021), se presenta una amplia serie de fotografías en blanco y negro coloreadas digitalmente. Se plantea, con total naturalidad y entrega a la causa justa y esforzada de la manipulación colorista de las tristes y demediadas imágenes en blanco y negro, que el coloreado llevaría a la reescritura ni más ni menos que de la «historia del mundo» (una nueva historia del mundo) y a dotar de mayor «realidad» (ergo, verdad, a esas imágenes): «La fotografía operó durante su primer siglo de existencia casi en exclusiva en blanco y negro, y debido a ello nuestra perspectiva del pasado es parcial y apagada» (sic). Un titular de El País de julio de 2021, en relación con el libro en cuestión («un libro reúne 200 fotos famosas coloreadas digitalmente en una sorprendente historia visual del mundo entre 1850 y 1960»), afirmaba que «los muertos parecen más muertos en colores» (Antón, 2021).

Argumentos (o lugares comunes, que no inofensivos), subyacentes a este maravillarse: 
1. El «color» (es decir, la fotografía en color, en este caso) sería más «real» que el blanco y negro.

Da igual que se trate de una completa reconstrucción, por muy documentada que esté, de colores deducidos o directamente inventados. ¿Cuál es el color original del suéter del confederado Lewis Powell en la cárcel? Pero, vayamos más allá: lo esencial de la escena de un reo, se aduce implícitamente, es el color de su jersey y de sus ojos. Terrorífico. Sobre todo porque se está utilizando el color de la vestimenta para dotar de verdad a una situación retórica y argumental que queda implícita y que tiene que ver con la dimensión socio-política, algo a lo que la fotografía o cualquier relato permite acceder, pero nunca se muestra explícitamente. Como en todos los relatos, el sentido nunca aparece a primera vista.

2. La «buena» fotografía es una duplicación del mundo en sí, la presencia apabullante del mítico referente extradiscursivo. Dejémonos de interpretaciones y liturgias del sentido, se nos insta. Así suena la reacción. Hay fotografías «verdaderas» y otras «falsas». Ante las supuestamente verdaderas no hay nada que interpretar ni leer, sólo tener fe. Vemos hacia dónde nos encaminamos. Territorio resbaladizo.

Volviendo a nuestro libro, se supone que el color dota de realidad (más nos valdría decir de «efecto de realidad»), de «verdad» (más nos valdría decir de «efecto de verdad»), porque, continúa el argumento, nosotros vemos el mundo en color, pero más valdría decir, vemos el mundo en Pantone X. Este argumento oblitera sistemáticamente la existencia de un relato, de un dispositivo, en nombre de la tan manida y dogmática «transparencia», reducto perfecto de todas las ocultaciones). La «realidad» de una imagen deriva de su capacidad para articular sentido, no tiene nada que ver con la duplicación de ninguna verdad objetiva o autoevidente (noción muy limitada, que no alcanza mucho mas allá del color de la vestimenta de un reo), nada que ver con ninguna Verdad. La verdad de la imagen es la de la propuesta, siempre abierta a la subversión, a la negación, igual, por otra parte, que la verdad científica, abierta siempre a la falsación. El camino del conocimiento es el del discurso no conclusivo, sistemáticamente cuestionado o revisado en un continuo proceso de búsqueda y cuestionamiento.

Que el color se ha utilizado para ahuyentar precisamente el fantasma de ese realismo plano que reivindican los «duplicacionistas», es obvio. No hay más que ver las películas de Cimino, Kaurismäki, Mackendrick, Angelopoulos o Godard, por citar sólo unos pocos, o los cuadros de Patinir o El Greco. Pero el «problema» ni siquiera es lo absurdo del argumento que subyace a la coloración «realista», sino lo que tiene de sintomático esta especie de «realismo ingenuo» en pleno siglo XXI en relación con los relatos mediáticos. Decir que colorear fotografías en blanco y 
negro devuelve «realidad» al pasado, es lo mismo que decir que la fotografía no es un lenguaje, que no es del orden del signo, sino de la consigna, del dogma; que la imagen no es un asunto de interpretación y propuesta, sino una cuestión de fe. Decir que la fotografía digital pone en cuestión la «verdad» de la fotografía implica asumir que la analógica era verdad, exudación directa del mundo retratado. Esa es la verdadera aberración. No es más falsa la fotografía digital que la analógica, ni más verdadera la segunda que la primera.

Ese borrado sistemático del discurso como espacio de poder y transformación en nombre de la supuesta transparencia del dispositivo cuyo output (en este caso una fotografía) se acoplaría de tal manera al mundo pretérito objetivado (que no objetivo), que se fundiría con el en el apabullante y mortal abrazo de la Verdad Una, es una constante en la aproximación al discurso mediático en la actualidad: cinematográfico, serial, fotográfico, ... y tiene que ver con algo que podemos denominar «imaginario digital», que se ha apropiado y ha «coloreado» con su azul chillón todo el imaginario analógico.

¿Cómo sustanciaríamos este discurso del «tiempo (ir)real» construido al ritmo de imperativos político-económicos, como es menester e inevitable?

A través del relato mediático (fotográfico, informativo, serial, cinematográfico...) se están reconstruyendo en el imaginario espectatorial la dimensión del poder y la legitimación de la misma, y de la identidad. A través de la puesta en escena audiovisual, incluso de tópicos y tramas aparentemente inocuos o considerados «mero entretenimiento", se legitima la lógica económica de un determinado momento histórico. Este régimen discursivo se caracteriza, al menos, por dos circunstancias en la actualidad: 1) el velamiento sistemático de la dimensión del poder en pos de la exacerbación de una privacidad despolitizada y compuesta por individuos estructuralmente apolíticos que deben exigir a los relatos «pureza» y «transparencia» (siempre y cuando el porridge luzca un buen photoshop en Instagram, transparencia sí y realismo también, pero no seamos bastos); y 2) el velamiento de los mecanismos de construcción del poder a través de modos de representación que se presentan a sí mismos como asépticos y fiel reflejo de un mundo extradiscursivo.

La reescritura audiovisual de la dimensión del poder procede en la actualidad desdibujando o velando dicha dimensión y recreando identidades despolitizadas y centradas en una noción reduccionista de lo privado. Esta reescritura está determinando en gran medida la construcción del imaginario cultural actual, con el consiguiente correlato de sus efectos en la conciencia cívico-política de la población, especialmente, de sectores específicos (los «nativos digitales»)

Las nociones de «industria cultural» y de «sociedad del espectáculo» que han articulado la crítica político-económica de la representación audiovisual, incluida la fotográfica, ya no resultan suficientes para abordar los modos de representación y los discursos dominantes del audiovisual en la sociedad digital. 
El relato audiovisual mainstream «basado en hechos reales» (tanto el que se ubica en el terreno documental como en el ficcional, ambos únicamente, desde nuestra perspectiva, diferenciables en términos retóricos, es decir, en términos de modos de recepción, no en términos de verdad, mentira u objetividad) está empezando a suplantar el rigor del discurso histórico, lo que lleva a que muchas producciones mainstream de corte histórico sean consumidas como manifestaciones de lo que «realmente ocurrió».

Planteémonos de nuevo la pregunta: ¿Para qué el enorme esfuerzo y el dispendio de recursos bien descrito en el prólogo del libro en en colorear fotografías en blanco y negro? Qué se pretende estar «añadiendo» ahí. Desde luego, no más verdad. Esas fotografías coloreadas son el bonito cadáver del Fake (es decir, de la Verdad). Esta parece ser la lógica: «coloreamos» el relato y por arte de birlibirloque, emerge triunfal la Verdad.

En el ámbito de los mass media hay una tendencia creciente y preocupante a confrontar el relato en términos dogmáticos, de verdad y mentira. El fake no es sino la otra cara de la moneda de una lógica que dice claramente que más allá del fake está la Verdad, que lo que no es fake es Verdad, no relato ni interpretación ni tentativa, es decir, no propuesta. La ciencia es tentativa, prueba y error; lo que la lógica del fake propone es que más allá de las supuestas noticias falsas existen noticias verdaderas, existen imágenes verdaderas en términos absolutos. La demagogia de esta propuesta es evidente. El gran problema, en realidad, no son las noticias falsas, es la lógica que la postulación del fake instaura, los modos de relacionarnos con el relato que instituye, con el relato mediático en este caso, pero con todo el ámbito de la representación en general. Vuelta a la caverna, podría decirse. No hay mayor efectismo que el de la Verdad. Lo espectacular, hoy, son los caminos del dogma. El color ha vuelto para, en efecto, dar más vida a los muertos....

\section{Referencias}

Amaral, Marina; Jones, Dan y García Cardiel, Jorge (2021). El color del tiempo: una historia visual del mundo 1850-1960. Madrid: Desperta Ferro Ediciones.

Antón, Jacinto (2021). Los muertos parecen más muertos en color. El País. Consultado el 21 de julio de 2021 en https://elpais.com/cultura/2021-07-14/los-muertosparecen-mas-muertos-en-colores.html 